\title{
The Innovativeness and Growth of Rural SMEs During the 1990s
}

\author{
DAVID NORTH and DAVID SMALLBONE \\ Centre for Enterprise and Economic Development Research, Middlesex University Business School, The Burroughs, Hendon, \\ London NW4 4BT, UK
}

(Received March 1998; in revised form July 1999)

North D. and Smallbone D. (2000) The innovativeness and growth of rural SMEs during the 1990s, Reg Studies 34, 145-157. The paper summarizes the results of a study of innovation in rural small and medium sized enterprises (SMEs) in England over the 1991-96 period. It is based on a survey of 330 firms drawn from 16 sectors and makes a comparison between similar SMEs in remote and accessible rural areas. Using a multi-dimensional index of innovation, relatively little overall difference is found in the level of innovation between SMEs in the different areas. A remote rural location is shown to influence innovation in different aspects of the business in different ways. The most innovative firms are shown to be those that have achieved the fastest growth and best employment creation during the 1990s.

Innovation New technology Rural SMEs Growth Employment

North D. et Smallbone D. (2000) L'innovation et la croissance des PME rurales pendant les années 1990, Reg Studies 34, 145-157. Cet article cherche à faire le résumé d'une étude sur l'innovation des PME rurales en Angleterre de 1991 à 1996. Elle est fondée sur une enquête auprès de 330 entreprises sélectionnées parmi 16 secteurs et les compare à des PME similaires situées dans des zones rurales isolées et accessibles. A partir d'une indice d'innovation multidimensionnelle, il s'avère que l'écart global entre les niveaux d'innovation des PME situées dans des zones différentes est peu importante. On démontre qu'un emplacement rural isolé peut influer sur l'innovation de manière différente suivant les diverses fonctions de l'entreprise. Les entreprises les plus innovatrices sont celles qui ont atteint le taux de croissance et la création d'emplois les plus élevés pendant les années 1990.

Innovation Nouvelle technologie

PME rurales Croissance Emploi

\section{INTRODUCTION}

Previous research has identified significant spatial variations within the UK in the innovativeness of small firms and in their propensity to adopt new technology, the implication being that this may reflect differences in regional and local environmental conditions as well as the characteristics of the entrepreneurs and businesses found in different types of location. At the regional scale, WYNARCZYK and THWAITES, 1997, p.172, showed that there is more innovative activity in the
North D. und Smallbone D. (2000) Ausmaß der Einführung von Innovationen und Wachstum kleiner und mittlerer Unternehmen (SMCs) in den neunziger Jahren, Reg Studies 34, 145-157. Dieser Aufsatz faßt die Ergebnisse einer Studie der Einführung von Neuerungen in kleinen und mittleren Firmen (SMEs) in ländlichen Gegenden Englands im Zeitraum 1991 - 1996 zusammen. Er stützt sich auf eine Umfrage unter 330 Firmen in 16 Sektoren, und stellt einen Vergleich zwischen SMEs in abgelegenen und leicht zugänglichen ländlichen Gebieten an. Es wird ein mehrdimensionaler Innovationsindex benutzt, und allgemein weniger Unterschied im Umfang der Innovation in SMEs verschiedener Gebiete festgestellt. Es wird gezeigt, daß ein abgelegenes ländliches Gebiet Innovation in verschiedenen Aspekten des Betriebes auf unterschiedliche Art und Weise beeinflußt. Am innovationsfreudigsten waren jene, welche in den neunziger Jahren die größten Wachstumsleistungen und die beste Stellenbeschaffung aufzuweisen hatten.

Innovation Neue Technologie

Kleine und mittlere Firmen auf dem Lande Wachstum Stellenbeschaffung

South East and South West regions in relation to the size of the small business population than in less favoured regions. They also showed that innovative small and medium sized enterprises (SMEs) in the South East performed better on a range of performance indicators including retained profits and exporting (although not employment growth) than innovative firms in other regions (THWAITES and WYNARCZYK, 1996). Other work has drawn attention to urban-rural differences in the innovativeness of SMEs. For example, a survey of over 2,000 SMEs throughout the UK 
revealed 'the existence of consistent and striking spatial variations in the level of technological and other innovative activity as between the urban and rural SMEs surveyed' (UNIVERSITY OF CAMBRIDGE Small Business Resear ch Centre, 1992, p. 74). These urban-rural differences were confirmed in a subsequent survey carried out in 1995 by the same researchers (COSH and Hughes, 1996). ${ }^{1}$ Not only were rural firms more likely to have made product innovations which were new to the firm over the 1992-95 period than their urban counterparts, but they were particularly likely to have made more innovations which were new to their industry.

The findings of other studies, however, have suggested that these urban-rural differences are overgeneralized and may be masking important differences between different types of rural area. In a study specifically designed to compare businesses in urban and rural locations, KEEBLE et al., 1992, found that it was firms in accessible rather than remote rural areas which compared favourably with firms in urban areas. Based on a sample of 1,022 businesses drawn from both manufacturing and service sectors, it was shown that firms in accessible rural areas had significantly higher ratings on a series of indicators measuring innovation, new products and technological expertise. This led the authors to the conclusion that 'accessible rural firms are more dynamic, innovative and technologically focused than their counterparts in either urban or remote rural locations' (KeEBle and Tyler, 1995, p. 989).

As well as this literature on spatial differences in the innovativeness of small firms, there has been an increasing interest in the role of regions as unique environments in which innovation takes place (Storper, 1995; Cooke and Morgan, 1998). Some authors have argued that innovatory activities will be more likely in regional environments in which there is a high level of untraded interdependencies between firms, agencies and institutions, and where there is a common way of perceiving and understanding problems and of finding solutions to them (CAMAGNI, 1991; Maillat and LeCoq, 1992; Tödtling, 1992). In other words, SMEs are most likely to interact with, and learn from, other firms and organizations within their region, such that the external assistance needed to achieve innovation is likely to come mainly from within the region. For example, in relation to innovation support systems, COOKE, 1995, p. 19, argues that 'the region [is] the optimal level of industrial, governmental, and technological support, especially for small and medium-sized enterprises'. The implication, therefore, is that SMEs in regions with weakly developed 'learning infrastructures' will be less innovative than similar firms in better provided regions. Thus remote rural regions will suffer in comparison to accessible rural and urban regions because of the lower density and more dispersed distribution of the business population, the relative lack of opportunities for local trading and subcontracting linkages (SMALLBONE et al., 1993), the absence of higher education and research institutions, and the relative lack of local business support agencies On the other hand, VAESSEN and KeEBLE, 1995, have argued that a more hostile business environment may have the effect of encouraging firms to become more, rather than less, innovative in order to try to overcome the constraints they are facing. Following this line of argument, SMEs in peripheral rural regions may put more effort into developing new products and markets than their counterparts in more central urban regions.

It is against the context of this debate that this paper takes a closer look at innovation and the adoption of new technology in rural SMEs in English regions using evidence from a recent study undertaken for the Rural Development Commission (RDC) (NORTH et al., 1997). A key objective of the study was to compare the innovative behaviour and performance of SMEs in 'remote' and 'accessible' rural locations. The specific aims of this paper are:

1. To analyse the extent of, and basis for, achieving innovation within rural SMEs, distinguishing between firms in different sectors and firms in different types of rural environment; in particular, we want to see whether SMEs in remote rural areas are less innovative than their counterparts in accessible rural areas, and if so, in what respects and for what reasons.

2. To analyse the relationship between innovation and the introduction of new technology on the one hand and the performance of rural SMEs on the other, and especially whether the level of innovativeness in a firm is associated with its rate of growth in sales turnover and employment.

Before summarizing some of the results of the study, the first part of the paper will discuss the way in which innovation has been conceptualized and measured.

\section{CONCEPTUALIZING INNOVATION}

Innovation is an elusive concept which is difficult to define. Basically, there are two key issues to consider here. Firstly, there is the question of whether the term innovation should only be used for developments and breakthroughs which are new within an industry or economy, or whether changes which are new to the firm itself should also be included, irrespective of how they compare with what other firms in the same industry or market segment are doing. Certainly some of the early work on innovation and SMEs (e.g. FREEMAN, 1971) tends to adopt the view that innovation involves making fundamental or radical changes comprising the transformation of a new idea or technological invention into a marketable product or process. Empirical work using the Science Policy Research Unit's Innovation Database (e.g. PAvitT et al., 1987; 
THWAITES and WyNARCZYK, 1996) has defined innovation as significant technical advances within a given industrial context. On the other hand, PORTER, 1990 , p. 45, views innovation as an attempt 'to create competitive advantage by perceiving or discovering new and better ways of competing in an industry, and bringing them to market'. Innovation in this sense is seen as leading to a higher order type of competitive advantage than that based on lower labour costs or using cheaper materials which may lead to a temporary price advantage. An approach to innovation which emphasizes the commercialization of ideas and methods that are new to the firm inevitably means that much innovation in practice can appear rather mundane and incremental rather than radical, depending upon an accumulation of small insights rather than on major breakthroughs.

The second issue relates to the breadth of the definition. According to PORTER (ibid.), innovation can be broadly defined to include both improvements in technology and better ways of doing things in all aspects of the business. This is compatible with the view expressed by SCHUMPETER, 1934, who, in his seminal work on entrepreneurship and economic development, referred to five types of innovation, including modifications to existing products as well as the development of new products, and recognizing a role for market, sourcing and organizational innovations as well as process innovation.

For the purposes of this study we recognize the value of 'the new to the firm definition' since most SMEs are likely to be involved in making more incremental changes based on generic technologies than on more radical and fundamental changes (ROSENBERG, 1992). Rather than regarding a firm as either innovative or not, it is arguably more useful to consider the degree or extent to which it is innovative (ROTHWELL and ZEGVELD, 1982) as well as the role that small firms play in relation to innovation in different types of sector (RizZONni, 1991; Rothwell, 1991). For example, innovation in small firms is likely to take the form of design modifications and incremental changes in mature, craft-based sectors (e.g. clothing or furniture) whereas in sectors which are more technology driven (e.g. electronic engineering), there are technologybased SMEs that may be at the forefront of innovative activity in specific fields.

To summarize, therefore, the approach which we have adopted to defining innovation has been based on four key principles:

1. The need to view innovation in terms of changes made by firms which are part of the process of maintaining and improving their competitiveness

2. The need to adopt a fairly broad view of what constitutes innovation by including changes across five different dimensions, namely: (1) products and services; (2) market development; (3) marketing methods; (4) production processes; and (5) the technology used in administration

3. The need to recognize different degrees of innovation which involves being able to position firms in terms of appropriate indicators of innovation

4. The recognition of the importance of the sectoral context as a framework for assessing the role of innovation as a factor influencing competitiveness.

\section{MEASURING INNOVATION}

Based on the application of the above principles, the study has involved assessing the extent to which rural SMEs have been innovative over a five-year period (1991-96) on each of the above five dimensions. We have identified and measured innovative behaviour on each dimension in the following ways:

1. Product and service innovation - the starting point was to ask the interviewed SME managers themselves whether they considered any of their products or services to be innovative in any way. If they replied positively, they were then asked to explain what was innovative about the product or service and what it could do. However, in order to overcome the limitations of relying solely on the opinions of SME managers themselves, we undertook a more systematic assessment of whether or not a particular firm's products or services were innovative by using sectoral information sources including interviews with representatives of sector organizations. This sectoral information has helped us assign each firm to one of three categories in terms of changes made over the 1991-96 period: (a) introducing 'highly innovative' products/services; (b) introducing 'fairly innovative' products/services; and (c) introducing no innovative products/services.

2. Market development - active market development via the generation of new types of customer and/or new geographical markets is central to a firm's commercial success. SME managers were therefore asked whether they had developed new market segments over the 1991-96 period and/or developed new non-local markets, including export markets.

3. Marketing methods - managers were asked if any methods for increasing sales (i.e. information about new markets, promotion, pricing and distribution) had been introduced since 1991 that were new to the firm. Managers were specifically asked about the use of the Internet for marketing purposes to identify those firms which were using more advanced and innovative methods.

4. Process technology and innovation - the first step here was to characterize the technology base of each surveyed firm, taking into account sectoral differences in the importance of technology as an influence on the competitiveness of SMEs. This involved asking managers to identify the technologically most 
sophisticated equipment used at each stage of the manufacturing process, or in their core service provision in the case of service sector firms. The type of equipment used was then coded into one of five categories: (a) hand tools/methods; (b)operator controlled equipment; (c) automated (but non computer based) equipment; (d) computer aided equipment; and (e) computer controlled equipment. To assess the extent to which firms were innovative in terms of introducing process equipment that was new to the firm between 1991-96, managers were asked if any new process equipment had been introduced during this period that involved more than straight replacement for existing equipment, i.e. the new equipment added some value to the firm's existing capability. By analysing the changes using information on technological developments at the sectoral level, it was possible to distinguish between process innovations that involved relatively standard technology and those involving more advanced, state of the art technology.

5. Use of computers/IT in administration - managers were asked if any investment had been made in computers/IT for use in administration between 1991-96 in order to measure whether firms were adopting new technology in this aspect of their business.

\section{An index of innovative activity}

As well as assessing the degree to which firms were innovative over the 1991-96 period on each of the above dimensions, we tried to measure their overall level of innovativeness by producing an index of total innovative activity (Table 1). The maximum score attainable is 10 and in order to summarize firms' total innovative activity, we have divided their total index scores into three groups based on the upper and lower quartiles. This enables us to identify a 'highly active innovator' group (above the upper quartile, i.e. an index score of 6 or more); a 'moderately active innovator' group (comprising the two middle quartiles, i.e. an index score of 3-5); and a group with a 'low level of innovation' (below lower quartile, i.e. an index score of $0-2)$.

\section{SURVEY OF RURAL SMES}

A key aspect of the research has been to compare innovation and the adoption of new technology by firms in remote and accessible rural areas. For this purpose we used a modified version of a classification of remote and accessible rural districts produced for the RDC (TARLING et al., 1993), the modification being that to be classified as 'rural', districts must contain at least $50 \%$ of their total population in settlements of less than 10,000 inhabitants. Rather than take remote and accessible rural districts from all English regions, a
Table 1. Index of total innovative activity

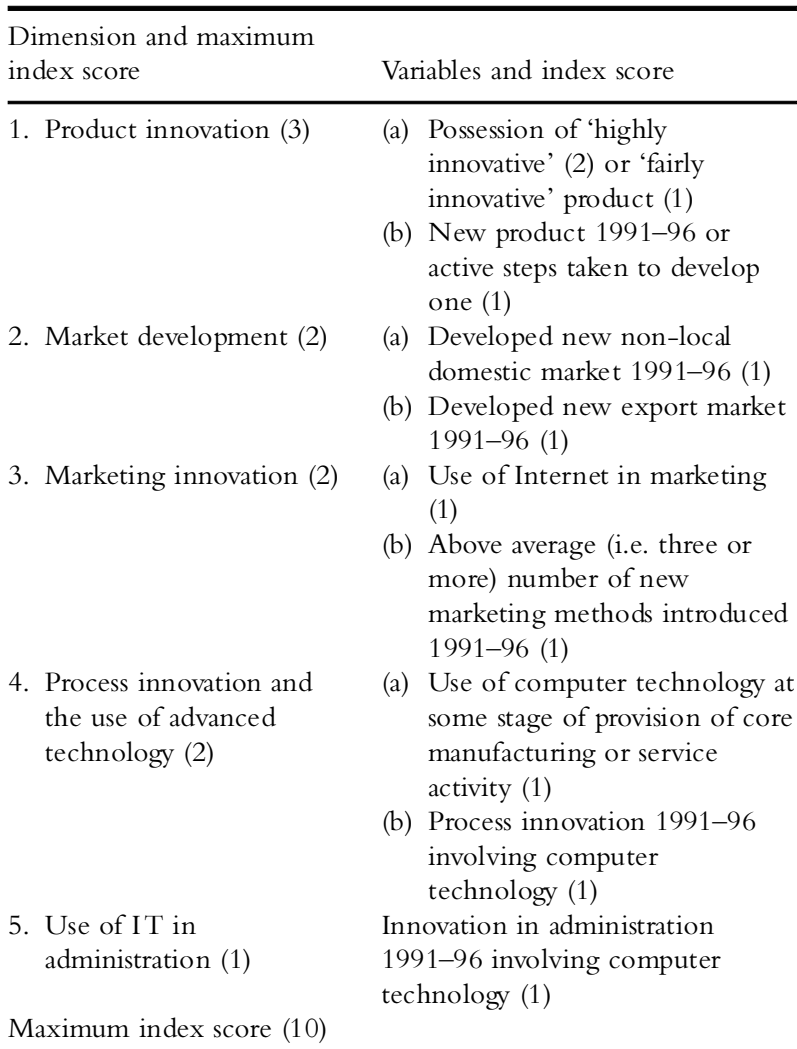

Note: Figures in brackets refer to the contribution to the total index score.

decision was taken to concentrate on three contrasting regions in order to make a reliable assessment of the extent and nature of innovative activity amongst SMEs in each region: the North (extended to include some districts in Yorkshire and Humberside, and Lincolnshire); the South West; and East Anglia (Fig. 1). Taken together, these three regions account for just over two-thirds of the RDC's list of 69 remote rural districts throughout England. Rather than select the accessible rural districts from regions such as the South East where the majority of rural districts have been classified as 'accessible', it was decided to select them from the same three regions as the remote districts. ${ }^{2}$ This has the advantage of helping to control for the effect of possible regional variations in sectoral structure and in the innovativeness of firms given the significantly higher level of innovations amongst small firms in the South East compared with other regions found in previous research (THWAITES and WYNARCZYK, 1996).

The study aimed to identify both manufacturing and service sectors which are representative of the sectoral composition of SMEs in remote rural areas not only throughout the three study regions, but throughout England as a whole. Because the main purpose of the accessible rural sample was to act as a reference point for the remote rural firms, it was important to keep the sectoral composition of the two samples constant. 


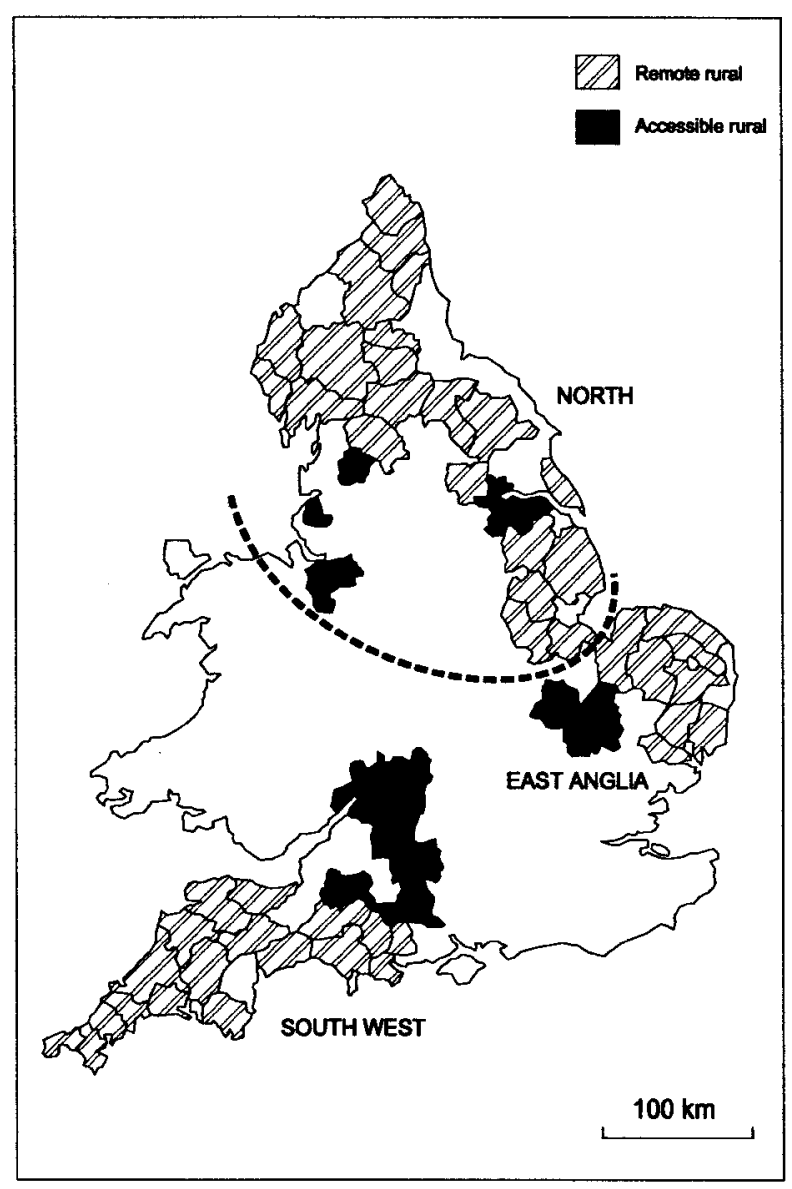

Fig. 1. Remote and accessible rural districts in the three study regions

The 16 selected sectors (eight manufacturing and eight services) are listed in Table 2.

A number of objectives underpinned the selection of firms for the study, namely: (1) to obtain equal numbers of firms in each of the three study regions; (2) to draw two-thirds of each region's sample from remote districts and one-third from accessible districts; and (3) to restrict micro firms (those employing less than 10) to less than one-third of the overall sample in order to achieve sufficient numbers of interviews with larger firms. A sampling frame was compiled from the various county business directories together with lists made available by the RDC's regional offices. Two types of interview were conducted. Telephone interviews were conducted with 275 firms, $65 \%$ of them in remote rural areas and 35\% in accessible rural areas. In addition, 55 firms were interviewed on a face-to-face basis in order to provide us with a more in-depth understanding of the innovation process, $60 \%$ of them being firms in remote rural areas and $40 \%$ in accessible rural areas. A total of 330 interviews were conducted between July and October 1996 out of a sample of 759 firms which met the above criteria, giving a response rate of $43 \%$.
Table 2. The distribution of surveyed firms between manufacturing sectors

\begin{tabular}{|c|c|c|c|}
\hline Sector & $\begin{array}{l}\text { Remote } \\
\text { rural }\end{array}$ & $\begin{array}{c}\text { Accessible } \\
\text { rural }\end{array}$ & Total \\
\hline Mechanical engineering & 15 & 7 & 22 \\
\hline Electronic engineering & 16 & 7 & 23 \\
\hline Instrument engineering & 12 & 6 & 18 \\
\hline Food & 16 & 11 & 27 \\
\hline Clothing & 16 & 7 & 23 \\
\hline Furniture & 15 & 8 & 23 \\
\hline Printing & 14 & 8 & 22 \\
\hline Other manufacturing & 14 & 8 & 22 \\
\hline Total manufacturing & $118(65 \cdot 5)$ & $62(34 \cdot 5)$ & $180(100)$ \\
\hline Wholesale & 14 & 6 & 20 \\
\hline Transport & 13 & 9 & 22 \\
\hline Auxiliary transport & 10 & 4 & 14 \\
\hline Post and telecommmunications & 9 & 6 & 15 \\
\hline Computer services & 13 & 6 & 19 \\
\hline $\mathrm{R} \& \mathrm{D}$ & 8 & 9 & 17 \\
\hline Business services & 14 & 10 & 24 \\
\hline Tourism & 12 & 7 & 19 \\
\hline Total services & $93(62)$ & $57(38)$ & $150(100)$ \\
\hline All sectors & $211(64)$ & $119(36)$ & $330(100)$ \\
\hline
\end{tabular}

Note: Percentage figures are given in parentheses.

\section{THE EXTENT OF INNOVATION IN RURAL SMES}

In this section of the paper we address the first of the aims by considering the extent of innovation and adoption of new technology in rural firms over the 1991-96 period, making a comparison between firms in remote and accessible areas. We interpret these findings in relation to the possible influence that various aspects of the rural environment may have had upon the innovativeness of rural SMEs. Each dimension of innovation will be considered in turn before considering the overall level of innovativeness in rural SMEs using the index of total innovative activity.

\section{Product and service innovation}

In terms of managers' own assessments of whether or not they had introduced innovative products and services over the 1991-96 period, just over half (58\%) of the rural SMEs replied positively. This happens to be very close to the $56 \%$ of firms which took part in the 1995 national SME survey and considered that they had introduced product and service innovations over the 1992-95 period (CosH and Hughes, 1996). Rural firms therefore do not appear to be any more or less innovative than firms elsewhere, at least when the definition of what is innovative is left to the managers themselves.

When we attempted a more systematic assessment based on information gained from sectoral experts and other sources, the proportion of firms whose products or services could be classified as innovative was lower. 
Table 3. Number of firms with innovative products by manufacturing sector

\begin{tabular}{lcrrr}
\hline Sector & $\begin{array}{c}\text { No. of } \\
\text { firms }\end{array}$ & $\begin{array}{c}\text { Non- } \\
\text { innova- } \\
\text { tive }\end{array}$ & $\begin{array}{c}\text { Fairly } \\
\text { innova- } \\
\text { tive }\end{array}$ & $\begin{array}{c}\text { Highly } \\
\text { innova- } \\
\text { tive }\end{array}$ \\
\hline Mechanical engineering & 22 & $11(50)$ & $3(14)$ & $8(36)$ \\
Electronic engineering & 23 & $5(22)$ & $8(35)$ & $10(44)$ \\
Instrument engineering & 18 & $6(33)$ & $4(22)$ & $8(44)$ \\
Food & 27 & $10(37)$ & $10(37)$ & $7(26)$ \\
Clothing & 23 & $14(61)$ & $6(26)$ & $3(13)$ \\
Furniture & 23 & $17(74)$ & $3(13)$ & $3(13)$ \\
Printing & 22 & $17(77)$ & $5(23)$ & 0 \\
Other manufacturing & 22 & $11(50)$ & $6(27)$ & $5(23)$ \\
Total manufacturing & 180 & $91(51)$ & $45(25)$ & $44(24)$ \\
\hline
\end{tabular}

Note: Percentage figures are given in parentheses.

Table 4. Number of firms with innovative services by service sector

\begin{tabular}{lcccc}
\hline Sector & $\begin{array}{c}\text { No. of } \\
\text { firms }\end{array}$ & $\begin{array}{c}\text { Non- } \\
\text { innovative }\end{array}$ & $\begin{array}{c}\text { Fairly } \\
\text { innovative }\end{array}$ & $\begin{array}{c}\text { Highly } \\
\text { innovative }\end{array}$ \\
\hline Wholesale & 20 & $18(90)$ & $2(10)$ & 0 \\
Transport & 22 & $18(82)$ & $3(14)$ & $1(5)$ \\
Auxiliary transport & 14 & $7(50)$ & $5(36)$ & $2(14)$ \\
Post and & & & & \\
$\quad$ telecommunications & 15 & $14(93)$ & $1(7)$ & 0 \\
Computer services & 19 & $9(47)$ & $7(37)$ & $3(16)$ \\
R\&D & 17 & $2(12)$ & $10(59)$ & $5(29)$ \\
Business services & 24 & $15(63)$ & $6(25)$ & $3(12)$ \\
Tourism & 19 & $12(63)$ & $7(37)$ & 0 \\
Total services & 150 & $95(63)$ & $41(27)$ & $14(9)$ \\
\hline
\end{tabular}

Note: Percentage figures are given in parentheses.

As shown in Tables 3 and 4, 44\% of the rural sample were considered to have introduced innovative products and services over the 1991-96 period, with more being classified as 'fairly innovative' (26\% of the total) than 'highly innovative' (18\% of the total). This more systematic assessment provides the basis for comparing the firms in remote and accessible rural areas. The same proportion had highly innovative products and services $(18 \%)$ and although a higher proportion of accessible rural firms had fairly innovative products and services (29\% compared with $24 \%$ ), the difference was too small to be statistically significant.

Even allowing for the fact that innovativeness needs to be interpreted in particular sectoral contexts, it is clear from our study that SMEs in certain sectors achieve much higher levels of product and service innovation than in others. At one level, there are differences between manufacturing and services. Half of the 180 manufacturing firms in the sample were considered to have introduced innovative products during the period and they were split equally between those classified as 'fairly innovative' (25\%) and those that were 'highly innovative' (24\%). In contrast, just over a third $(36 \%)$ of the 150 service firms were considered to have developed innovative services, three-quarters of them categorized as 'fairly innovative'. Thus relatively few (9\%) of the rural service firms could be considered to have developed 'highly innovative' services, which is very similar to the $7 \%$ of service firms in the UK sample of the Community Innovation Survey which were categorized as being 'novel innovators' (CRAGGS and JONES, 1998). Thus rural service firms are no different from service firms generally in this respect, reflecting the difficulties of achieving high levels of innovation within the service sector, at least in terms of the core service that is offered.

At a more detailed level, there were some clear sectoral variations in the degree to which the surveyed rural SMEs had introduced innovative products and services. Firms in the electronic engineering, instrument engineering and $\mathrm{R} \& \mathrm{D}$ sectors were the most likely to have innovative products and nearly half of the firms in the first two of these sectors had 'highly innovative' products. These are technology based sectors where the majority of firms possessed proprietary products and an active programme of product improvement and development was central to a firm's ability to maintain competitiveness. Sectors where the possession of innovative products was much less common and the level of active product management below average included the printing, wholesaling and transport sectors. The scope for seeking competitive advantage through product innovation proved to be much more limited in these sectors than in the engineering based sectors. The food sector was an example of where firms needed to be actively managing their product portfolio (e.g. by making modifications to existing products or changes in presentation/packaging) in order to survive but where it was more difficult for small firms to be 'highly innovative' in terms of developing fundamentally new products.

These findings draw attention to the importance of the sectoral structure to the innovativeness of rural economies. Whilst we may have found no significant difference between the remote and accessible rural SMEs with respect to product and service innovation, it needs to be recognized that this is based on comparing two matched samples in terms of their sectoral composition. A comparison of the sectoral structure of all business establishments in remote and accessible rural areas within the three study regions shows that those sectors with higher proportions of highly and fairly innovative SMEs are somewhat better represented in the accessible rural areas. Thus $31.5 \%$ of manufacturing establishments in the accessible rural areas are in the engineering sectors compared to $29.5 \%$ in the remote rural areas, and $17 \cdot 2 \%$ of service establishments are in the most innovative service sectors (especially computer services and business services) compared to $13 \cdot 8 \%$ in the remote rural areas. In fact, these differences become greater if the comparison is based on accessible rural areas in all English regions (and therefore including the South East); the equivalent proportions are then $32.8 \%$ 
for manufacturing and 19\% for services. Overall, therefore, the degree of product/service innovation in remote rural areas is less than in accessible rural areas because a smaller proportion of their SMEs are in the more innovative sectors. It is not because individual firms located in remote rural areas in any given sector are less active in terms of product/service innovation than their accessible rural counterparts.

\section{New market development}

Rural SMEs proved to be actively involved in new market development over the 1991-96 period, with $72 \%$ of them having developed new non-local geographical markets and/or new market segments. Our previous research has drawn attention to the need for rural SMEs to be more active than their urban counterparts in developing new markets because of the limited scale and scope of many local markets in rural areas (NORTH and SMALlbONe, 1996). Our evidence here tends to support the argument of VAESSEN and KeEBLE, 1995, that the constraints of operating in certain types of 'hostile' business environment may induce firms to become more innovative. This view is further supported by the fact that a slightly higher proportion of remote than accessible rural SMEs (51\% compared with 46\%) developed new national or international markets during the 1991-96 period.

The research has also demonstrated a clear link between product and service innovation and new market development as the firms with innovative products were more likely (statistically significant at the 0.01 level) to have developed new markets than those without innovative products. The difference is particularly marked with respect to the development of new geographical markets (71\% of firms with 'highly innovative' products did so compared with $41 \%$ of those without innovative products). As found in the 1995 national SME survey (COSH et al., 1997), the possession of an innovative product appears to significantly increase a firm's export potential; $52 \%$ of rural firms with 'highly innovative products' had developed new export markets between 1991-96 compared with 20\% of those without innovative products. Innovative firms are clearly making an important contribution to rural economic development through generating income from non-local sales. Geographical market development including exporting constitutes an important way in which rural SMEs are engaging in national and global networks which, as CAMAGNI, 1991, has argued, are essential for long term regional growth and likely to be beneficial to the learning and innovation process within SMEs.

\section{New marketing methods}

Considering the extent of new market development during the 1991-96 period, rural SMEs appear to have been less innovative than might be expected in terms of the marketing methods which they use. Although about two-thirds of surveyed rural SMEs had introduced some aspect of marketing (particularly sources of market information and promotion such as using trade literature and attending trade fairs and exhibitions) which was new to the firm over the 1991-96 period, in only a minority of cases can the methods be described as highly innovative. As others have noted (ILBERY and CLARK, 1995), the Internet promises to extend the market reach of firms in remote rural areas in various ways, including advertising goods and services using websites, ordering and paying for goods electronically, and providing better customer support through remote diagnostics. However, only $9 \%$ of the surveyed rural firms had started using the Internet for marketing purposes at the time of the survey in 1996. Comparative evidence suggests that this is an area where rural SMEs are lagging behind SMEs generally since a national survey showed $16 \%$ of UK firms with less than 100 employees to be using the Internet (EUROPEAN INFORMATION TECHNOLOGY OBSERVATORY (EITO), 1995).

There is evidence that distance from major urban centres is affecting the diffusion of telematics since it was the remote rural service firms which were least likely to be using the Internet. Service sector firms in accessible rural areas were almost twice as likely to have started using the Internet between 1991 and 1996 than those in remote rural areas (21\% and 12\% respectively) (chi square only significant at $0 \cdot 12$ ). Moreover, this difference was most apparent $(40 \%$ and $23 \%$ respectively) in those service sectors that were high Internet users (i.e. business services, post and telecommunications, and $\mathrm{R} \& \mathrm{D})$. This lower take-up of new technology amongst remote rural service firms is an indication of limitations in their learning environment compared with that experienced by firms in more accessible rural and urban locations. Not only is there less peer group pressure from local competitors and other firms to keep abreast of developments in telematics, but also the kinds of business support institutions providing technology awareness training are much thinner on the ground than in more urban environments. It would be ironic if the effect of the Internet was to make remote rural firms more rather than less marginal, given its alleged distance shrinking benefits.

\section{Process innovations}

The majority of all rural manufacturing firms (71\%) made some change to production equipment during the 1991-96 period that involved the introduction of equipment that was more than a straight replacement and there was only modest variation between sectors in this respect (Table 5). However, when advanced technology is defined as equipment that is either computer assisted or computer controlled, just over a third 
Table 5. The introduction of new production equipment by manufacturing sector, 1991-96

\begin{tabular}{|c|c|c|c|c|c|c|c|c|c|}
\hline \multirow[b]{2}{*}{ Sector } & \multicolumn{2}{|c|}{$\begin{array}{l}\text { Computer assisted/ } \\
\text { controlled equipment }\end{array}$} & \multicolumn{2}{|c|}{$\begin{array}{l}\text { Auto or semi-auto } \\
\text { only }\end{array}$} & \multicolumn{2}{|c|}{$\begin{array}{l}\text { Semi-auto methods } \\
\text { only }\end{array}$} & \multicolumn{2}{|c|}{ Some change } & \multirow[b]{2}{*}{$N$} \\
\hline & No. & $\%$ & No. & $\%$ & No. & $\%$ & No. & $\%$ & \\
\hline Mechanical engineering & 9 & 41 & 7 & 32 & 3 & 14 & 16 & 73 & 22 \\
\hline Electronic engineering & 11 & 48 & 6 & 26 & 1 & - & 17 & 74 & 23 \\
\hline Instrument engineering & 7 & 39 & 4 & 22 & 2 & 11 & 11 & 61 & 18 \\
\hline Food, drink and tobacco & 6 & 22 & 15 & 56 & 9 & 33 & 21 & 78 & 27 \\
\hline Leather and clothing & 5 & 22 & 10 & 43 & 9 & 39 & 15 & 65 & 23 \\
\hline Furniture & 4 & 18 & 10 & 45 & 8 & 36 & 14 & 64 & 22 \\
\hline Printing & 13 & 59 & 5 & 23 & 3 & 14 & 18 & 82 & 22 \\
\hline Other manufacturing & 8 & 38 & 6 & 29 & 4 & 19 & 14 & 67 & 21 \\
\hline All manufacturing sectors & 63 & 35 & 63 & 35 & 39 & 22 & 126 & 71 & 178 \\
\hline
\end{tabular}

Table 6. The introduction of new equipment by service sector SMEs, 1991-96

\begin{tabular}{|c|c|c|c|c|c|}
\hline \multirow[b]{2}{*}{ Sector } & \multicolumn{2}{|c|}{$\begin{array}{c}\text { Computer assisted/ } \\
\text { controlled } \\
\text { equipment }\end{array}$} & \multicolumn{2}{|c|}{ Some change } & \multirow[b]{2}{*}{$N$} \\
\hline & No. & $\%$ & No. & $\%$ & \\
\hline Wholesale & 5 & 25 & 8 & 40 & 20 \\
\hline Transport & 4 & 18 & 9 & 41 & 22 \\
\hline Auxiliary transport & 5 & 36 & 6 & 43 & 14 \\
\hline \multicolumn{6}{|l|}{ Post and } \\
\hline telecommunications & 4 & 27 & 5 & 33 & 15 \\
\hline Computer services & 9 & 53 & 10 & 59 & 17 \\
\hline $\mathrm{R} \& \mathrm{D}$ & 6 & 40 & 6 & 40 & 15 \\
\hline Business services & 15 & 71 & 16 & 76 & 21 \\
\hline Tourism and leisure & 5 & 26 & 9 & 47 & 19 \\
\hline All service sectors & 53 & 37 & 69 & 49 & 143 \\
\hline
\end{tabular}

Note: Seven firms are not included in this table.

of all manufacturing firms had adopted such methods between 1991 and 1996. Whilst the propensity of service sector firms to have introduced some type of new equipment into their core service provision between 1991 and 1996 was considerably below that of manufacturing firms, in the majority of cases it did involve some type of computer equipment (Table 6).

At a more detailed level, it was those manufacturing sectors in which process technology was at a relatively high level overall in 1996 where firms were the most active in introducing advanced technology (i.e. printing, electronic engineering, mechanical engineering and instrument engineering). Sectoral conditions define the parameters for competitiveness and the majority of firms in these sectors need to keep up-todate in terms of technology if they are to compete successfully, whatever their size. This applied equally to firms in remote and accessible rural areas.

By contrast, in those manufacturing sectors with a relatively low level of computer use (i.e. furniture, clothing and food processing), process changes typically involved less sophisticated, non-computerized methods. It is in these sectors where the remote rural firms have been noticeably less active in adopting advanced technology than their accessible rural area counterparts. If we focus solely on the use of computer technology in the main production process, the firms located in remote rural areas showed a lower level of use of computer aided and computer controlled equipment than firms in accessible rural areas $(31 \%$ and $44 \%$ of firms respectively) (chi square only significant at the $0 \cdot 1$ level). Moreover, they were found to use advanced technology less intensively when they did have it. In addition, remote rural firms in these below average computer using sectors were found to have been less active than their accessible rural counterparts in introducing computer equipment during the $1991-96$ period $(15 \%$ and $31 \%$ of firms respectively). These differences were also reflected in terms of lower annual investment levels per employee in these sectors; over the 1991-96 period, the median annual investment per employee was $£, 667$ in remote rural areas, compared to $\mathcal{f}, 1,000$ in accessible rural areas. Whilst this lower level of process innovation may be partly a reflection of the inferior nature of the learning environment in remote rural areas compared with other types of location, we would argue that the lower investment in advanced technology does represent a short term rational response by the owners and managers of these firms to the conditions facing them in their local business environment. As we have found previously, the lower cost of labour in these remote rural labour markets does encourage firms in these more craft-based sectors to compete using more labourintensive production methods rather than modernizing their production process equipment (NORTH and Smallbone, 1995, 1996). However, the use of innovation to achieve higher order competitive advantages is likely to be the best strategy from the point of view of achieving sustainable economic growth in these remote rural economies.

\section{Index of total innovation}

When all five dimensions of innovation are considered together, it appears that remote rural manufacturing firms were, if anything, slightly more innovative than 
their accessible rural counterparts; $24 \%$ of remote rural manufacturing firms achieved 'highly active innovator' status and 54\% 'moderately active innovator' status, compared with $24 \%$ and $47 \%$ respectively in the accessible rural areas. On the index of total innovative activity, the mean score on the 10-point scale for remote rural manufacturing firms was $4 \cdot 12$ (median 4) compared with 3.81 (median 4) for their accessible rural counterparts. In contrast, service firms in remote rural areas were noticeably less innovative than their accessible rural counterparts (chi square only significant at the $0 \cdot 1$ level). The proportion of firms in the low innovation category was much higher in the remote than accessible rural areas (37\% and $21 \%$ respectively); the mean index score for remote rural service firms was 3.45 (median 3) compared with 4.00 (median 4) for their accessible rural counterparts. This latest evidence, therefore, indicates that when a broad definition of innovation is adopted, it is service firms rather than manufacturing firms in remote rural areas which are lagging behind their counterparts in accessible rural areas.

With the possible exception of the use of the Internet, it is questionable whether the innovative capability of remote rural firms has been adversely affected by the relative lack of opportunities for local networking and clustering compared to accessible rural and urban locations. It is interesting to consider our evidence relating to the sources of ideas and expertise relating to product and service innovation at this point. Twothirds of the interviewed owner/managers said their innovations were developed internally without any involvement from other individuals, firms or agencies and only $3 \%$ were totally dependent upon external support, leaving the other third as having some external input to the process. Although it may be tempting to suggest that this high level of self-sufficiency in these rural SMEs is itself an indication of the absence of a local innovative milieu, it should be noted that our findings are broadly consistent with national level evidence. The University of Cambridge national study found that $68 \%$ of the surveyed firms considered the firm itself to be a 'very significant' or 'crucial' source of information for innovation compared with 48\% giving an equivalent rating for clients or customers, and $38 \%$ for suppliers of equipment, materials and components, these being the two most frequently used external sources (CosH and Hughes, 1998, p. 43). The dependence of SMEs on internal rather than external information and expertise for making innovations may be a general characteristic of SMEs in the UK rather than a particular feature of rural SMEs.

Once again, more detailed examination indicates that a firm's propensity to make use of external assistance in the process of developing innovatory products and services depends upon its sector. Innovative firms in the instrument engineering and printing sectors were three times more likely to make use of external assistance than their counterparts in other sectors, reflecting the greater technical sophistication of products in the case of instrument engineering and advances in production process technology in the case of printing making it necessary for firms to buy in specialist expertise (ROTHWELL, 1991). There was little indication that this external assistance was being drawn from the surrounding rural region since these more technologically orientated rural firms are able to access sectoral know-how and advice from further afield. Significantly, very few of the interviewed firms considered lack of local sectoral contacts to be a constraint on their ability to innovate. Certainly in the more advanced technology sectors (see also KEEBLE et al., 1999), innovation is likely to depend at least as much upon a firm's ability to engage in national or global networks as on the strength of the local innovative milieu.

\section{INNOVATION AND THE GROWTH PERFORMANCE OF SMES}

We now turn to the second aim of the paper which is to analyse the relationship between innovation and the introduction of new technology in rural SMEs on the one hand and their performance on the other. Of particular interest is the degree to which the most innovative firms have achieved the best growth performance in terms of sales turnover and employment generation over the period. Previous research leads us to expect a relationship. For example, FrEEMAN, 1994, p. 81, writes, 'fastest growing firms are distinguished by their capacity for a flow of incremental innovations as well as (more rarely) outstanding success with a radical innovation'. Moreover, WYNARCZYK and ThWAites, 1997, found that the innovative small firms in their study grew significantly in terms of assets, turnover and (most notably) exports compared with their control group. However, it is important to stress that we do not see a simple cause and effect relationship between innovation and growth, but rather an interdependent and mutually reinforcing one.

\section{Product and service innovation}

The study shows, unequivocally, that the most innovative rural firms are also the best performing ones. The firms which introduced 'highly innovative' products or services were significantly faster growing businesses than those with 'fairly innovative' or 'non innovative' ones, achieving an $80 \%$ increase in sales turnover in real terms over the 1990/91 to 1994/95 period (or an additional $£, 268,000$ of sales based on the median change per firm) compared with a $20 \%$ and $29 \%$ increase respectively. Moreover, they increased their employment by $50 \%$ between 1991 and 1996 compared with $27 \%$ and $22 \%$ increases for the other firms. The average (based on the median value) firm with 'highly innovative' products or services went from having 13 employees in 1991 to 20 by 1996 . Job creation therefore 
appears to be clearly linked to a high level of product and service innovation in these rural SMEs.

\section{Process innovation}

There was also some tendency for firms that were active in upgrading their process technology between 1991 and 1996 to be the better performing firms in terms of sales growth during this period. Growing firms showed a higher propensity to have introduced computer assisted or computer controlled equipment over the 1991-96 period than stable or declining firms; thus $39 \%$ of growing manufacturing firms introduced new computer based equipment compared with $27 \%$ of stable/declining ones, and $48 \%$ of growing service firms compared with $28 \%$ of stable/declining ones. Moreover, a comparison of the median real turnover change of firms that introduced new computer assisted controlled equipment with that of firms that did not introduce such equipment (65\% and $17 \%$ respectively) supports the view that firms that were active in making changes in process technology tended to be the better performing firms, at least in terms of sales growth.

Significantly, there is no evidence of technological change resulting in a net reduction of employment. This is explained by the fact that any savings in labour time resulting from process innovations had been more than compensated for by the overall growth in sales in firms that had been active in making process changes.
Manufacturing firms introducing computer assisted/ controlled equipment achieved a median employment increase of seven jobs and those making some change in process equipment an increase of five jobs, compared with no increase in the case of firms making no changes. Although the differences are less clear cut in the case of services, firms that had been active in introducing new process equipment typically created more jobs per firm, there being a median increase of 2.5 jobs for those firms introducing computer based equipment and two jobs for firms making some process changes, compared with no increase in the case of those firms making no changes. Thus process innovation, as well as product/service innovation, tends to be associated with employment growth in these rural SMEs. Any technological displacement that does occur is likely to be overshadowed by increased employment resulting from business growth.

\section{Total innovative activity}

When all five dimensions of innovation are combined, it is clear that the fastest growing businesses were the firms which attained 'highly active innovator' status, achieving a median turnover growth (in real terms) of $77 \%$ over the 1991-95 period compared with increases of $35 \%$ for the 'moderately active innovators' and 9\% for the firms with 'low levels of innovation'. As shown in Fig. 2, 'highly active innovators' in manufacturing

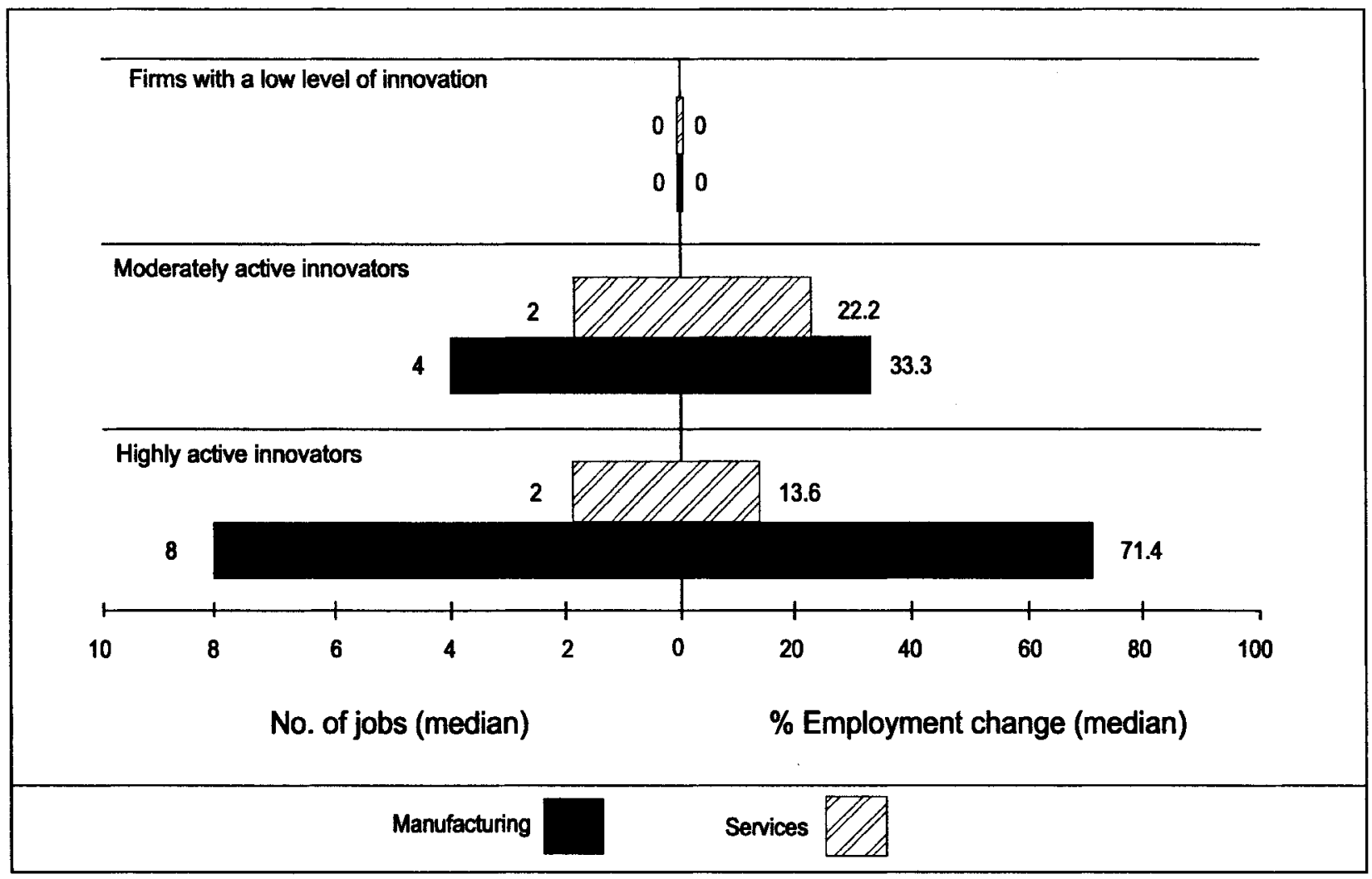

Fig. 2. Total innovative activity and employment change in manufacturing and services 
achieved a median employment increase of eight jobs over the 1991-96 period which was double that of the 'moderately active innovators'. The differences were less obvious in the case of the service sectors, the 'highly active innovators' increasing their employment by a median of two jobs (although a mean of 11 jobs) as did the 'moderately active innovators' (but a mean of five jobs), compared with no change in the case of firms with a 'low level of innovation'. The key implication of this analysis is that the best chances of job creation within SMEs in rural areas lie with the most innovative firms, especially in manufacturing.

\section{CONCLUSIONS}

The starting point for this research was the indication arising from previous work that firms in remote rural areas may be lagging behind firms in accessible rural areas and urban areas in terms of innovation and the adoption of new technology. The research started with the expectation that, within our three study regions, the firms in remote rural locations will have been less active on various dimensions of innovation than their counterparts in accessible rural locations, not least because the supporting learning infrastructure is likely to be less well developed. It is rather surprising, therefore, that the results do not indicate a clear cut difference between firms in remote and accessible rural areas.

Insofar as being located in a remote rural environment has affected innovation levels in firms, our conclusion is rather equivocal. In some respects, notably in relation to new market development, it appears to have stimulated innovation, showing how the need to overcome local constraints can induce firms to become more innovative than they would otherwise be. Also, there are examples from our research of how firms in some sectors (notably food and tourism) can derive their innovativeness from being in a rural environment by introducing to the market products based on traditional rural craft skills. In other respects, however, being located in a remote rural environment appears to have been a barrier to innovation. This has undoubtedly been so with respect to the use of the Internet by rural service firms and may be an indication of where the additional costs of delivering effective business and technology support in areas where business densities are low is slowing down the diffusion and adoption of new technologies. The more poorly developed telecommunications infrastructures in remote rural areas are likely to become an increasing problem here (RURAL Development Commission, 1996) The lower level and intensity of use of advanced technology in those manufacturing sectors which are below average users of technology is another example, although we would argue that the explanation has as much to do with the preference for a more labour-intensive form of development as with a lack of awareness of advanced technologies. In those sectors which are above average users of advanced technology, process innovation in remote rural firms compares favourably with that of their accessible rural counterparts, and there is little indication that their ability to use external sources of information and expertise, albeit non-local ones, has been adversely affected by their remote rural location. We conclude therefore that there is no clear indication from this research that being located in a remote rural environment is having an adverse effect on the ability of SMEs to innovate overall, but rather that it has various influences on the motivation and ability of owner managers to make innovations in different aspects of the firm. To survive in remote rural areas, SMEs need to be adaptable, and this can result in them being more innovative in some respects than firms elsewhere.

The research has also highlighted the importance of analysing innovation within the context of particular sectors, and has shown major differences between sectors in the extent and nature of the various dimensions of innovation covered by the study. From the point of view of considering the innovativeness of regional and local economies, therefore, this emphasizes the effects that the sectoral composition of the SME population will have on the overall levels of innovation found. This is where remote rural economies are at a disadvantage compared with accessible rural economies. In aggregate SMEs in remote rural areas are less innovative than SMEs in accessible rural areas because firms in the more innovative sectors (such as instrument and electronic engineering, $\mathrm{R} \& \mathrm{D}$, and business and computer services) are under represented compared with accessible rural areas, and especially when these areas within the South East region are included in the comparison. ${ }^{3}$ Given the clear relationship that the study has shown between the level of innovative activity in SMEs and their propensity to grow and create employment, the future strength of remote rural economies may partly depend upon being able to stimulate small business activity in these more innovative sectors. At the same time, however, because of the difficulties of attracting firms in these sectors to remote rural locations, it also justifies an innovation-led strategy of business support and economic development applied to all sectors within remote rural areas and lagging regions in general.

Acknowledgements - The research on which this paper is based was commissioned by the Rural Development Commission and we would like to thank the RDC's officers and business advisers for their helpful comments and insights at various stages of the research. We should emphasize, however, that they are not responsible for the views expressed in this paper. We would also like to acknowledge the valuable contribution of researchers within the Centre for Enterprise and Economic Development Research, Middlesex University Business School, to the interview survey and subsequent analysis; in particular we would like to thank Robert Baldcock, Lisa Clarke, Martina Freiberg, Christos Kalantaridis, David Mason and Jacqueline Parkes. The useful comments and suggestions of three anonymous referees were gratefully received. 


\section{NOTES}

1. It should be noted that the latest national survey $(\mathrm{COSH}$ and Hughes, 1998) covering the 1994-97 period did not find any difference in the frequency of innovation between the surveyed urban and rural firms.

2. We tested the remote/accessible classification using a number of distance measures and, as shown in Table 7, it is clear that the remote rural districts are significantly further from a number of key locations than the accessible rural districts.

3. It might be noted here that in the comparison of remote and accessible rural locations by KeEBLE et al., 1992, a large proportion of the accessible rural sample were drawn from the South East region. This may help account for the clearer difference they found between firms in remote and accessible rural locations compared with the findings of the present study.
Table 7. Distance of firms in remote/accessible areas from key locations

\begin{tabular}{lcc}
\hline & \multicolumn{2}{c}{ Mean distance (miles) } \\
\cline { 2 - 3 } Key location & $\begin{array}{c}\text { Remote rural } \\
\text { areas }\end{array}$ & $\begin{array}{c}\text { Accessible rural } \\
\text { areas }\end{array}$ \\
\hline Distance to nearest motorway & $19.2 \star \star \star$ & 8.9 \\
$\quad$ junctions & & \\
Distance to town of 200,000 & $61.0 \star \star \star$ & 41.9 \\
$\quad$ population & $45.1 \star \star \star$ & 34.5 \\
Distance to local airport & $157.0^{\star \star \star}$ & 90.4 \\
Distance to international airport &
\end{tabular}

Note: Value of $t$ significant at $\star \star \star 0.001$ level.

\section{REFERENCES}

CAMAGNi R.(1991) Local 'milieu', uncertainty and innovation networks: towards a new dynamitheory of economic space, in Camagni R. (Ed) Innovation Networks: Spatial Perspectives, pp. 121-44, Bellhaven Press, London.

Сооке P. (1995) Planet Europe: network approaches to regional innovation and technology management, Technol. Mgt. 2, $18-30$.

Cooke P. and Morgan K. (1998) The Associational Economy: Firms, Regions and Innovation. Oxford University Press, Oxford/ New York.

Cosh A. and Hughes A. (Eds) (1996) The Changing State of British Enterprise: Growth, Innovation and Competitive Advantage in Small and Medium Sized Firms 1986-95. ESR C Centre for Business Research, University of Cambridge.

Cosh A. and Hughes A. (Eds) (1998) Enterprise Britain: Growth, Innovation and Public Policy in the Small and Medium Sized Enterprise Sector 1994-97. ESR C Centre for Business Research, University of Cambridge.

Cosh A., Hughes A. and Wood E. (1997) Innovation, international competition and export performance in the British SME sector, paper presented to the Innovation and Performance of SMEs Conference, 17 March, University of Cambridge.

Craggs A. and Jones P. (1998) UK results from the Community Innovation Survey, Econ. Trends 539, 51-57.

European Information Technology Observatory (EITO) (1995) European Information Technology Observatory Report. EITO, Frankfurt.

Freeman C. (1971) The Role of Small Firms in Innovation in the United Kingdom since 1945: Report to the Bolton Committee of Inquiry on Small Firms, Research Report No. 6. HMSO, London.

Freeman C. (1994) Innovation and growth, in Dodgson M. and Rothwell R. (Eds) The Handbook of Industrial Innovation. Edward Elgar, Cheltenham/Brookfield.

Ilber y B. and Clar k D. (1995) Telematics and rural development: evidence from a survey of small businesses in the European Union, Europ. Urban \& Reg. Studies 2(1), 55-68.

Keeble D., Lawson C., Moore B. and Wilkinson F. (1999) Collective learning processes, networking and 'institutional thickness' in the Cambridge region, Reg. Studies 33(4), 319-32.

Keeble D. and Tyler P. (1995) Enterprising behaviour and the urban-rural shift, Urban Studies 32(6), 975-97.

Keeble D., Tyler P., Broom G. and Lewis J. (1992) Business Success in the Countryside: The Performance of Rural Enterprise. HMSO, London.

Maillat D. and LeCoq B. (1992) New technologies and transformation of regional structures in Europe: the role of the milieu, Entrepreneurship \& Reg. Develop. 4(1), 1-20.

North D. and Smallbone D. (1995) The employment generation potential of mature SMEs in different geographical environments, Urban Studies 32(9), 1,517-34.

North D. and Smallbone D. (1996) Small business development in remote rural areas: the example of mature manufacturing firms in Northern England, J. Rural Studies 12(2), 151-167.

North D., Smallbone D. and Baldock R. (1997) Innovation and New Technology in Rural SMEs, Research Report No. 33. Rural Development Commission, London/Salisbury.

Pavitt K., Robson M. and Townsend J. (1987) The size distribution of innovating firms in the UK: 1945-1984, J. Ind. Econ. 45, 297-306.

Porter M. (1990) The Competitive Advantage of Nations, Methuen, London.

Rizzoni A. (1991) Technological innovation and small firms: a taxonomy, Int. Small Bus. J. 9(3), 31-42.

Rosenberg N. (1992) Science and technology in the twentieth century, in Dosi G., Gianetti R. and Toninelli P. (Eds) Technology and Enterprise in Historical Perspective. Clarendon, Oxford.

Rothwell R. (1991) Networking and innovation in European manufacturing firms, Technovation 11(1), 93-112. 
Rothwell R. and Zegveld W. (1982) Innovation and the Small and Medium Sized Firm. Frances Pinter, London.

Rural Development Commission (1996) Telecommunications Development in Rural England, Research Report No. 28. Rural Development Commission, London/Salisbury.

Schumpeter J. (1934) The Theory of Economic Development, Harvard University Press, Cambridge.

Smallbone D., North D. and Leigh R. (1993) The growth and survival of mature manufacturing small and medium sized enterprises in the 1980s: an urban-rural comparison, in CURRAn J. and STOREy D. (Eds) Small Firms in Urban and Rural Locations, pp. 79-131. Routledge, London/New York.

STOR PER M. (1995) The resurgence of regional economies, ten years later: the region as a nexus of untraded interdependencies, Europ. Urban \& Reg. Studies 2(3), 191-221.

Tarling R., Rhodes J., North J. and Broom G. (1993) The Economy of Rural England, Strategy Review, Topic Paper No. 4. Rural Development Commission, London/Salisbury.

Thwaites A. and Wynarczyk P. (1996) The economic performance of innovative small firms in the South East region and elsewhere in the UK, Reg. Studies 30(2), 135-49.

Tödthing F. (1992) Technological change at the regional level: the role of location, firm structure, and strategy, Environ. E Plann. A 24, 1,565-84.

University of Cambridge Small Business Research Centre (1992) The State of British Enterprise: Growth, Innovation and Competitive Advantage in Small and Medium Sized Firms. Small Business Research Centre, University of Cambridge.

Vaessen P. and Keeble D. (1995) Growth-oriented SMEs in unfavourable regional environments, Reg. Studies 29, $489-505$.

WynARCZyk P. and ThWAites A. (1997) The economic performance, survival and non-survival of innovative small firms, in Oakey R. and Mukhtar S. (Eds) New Technology-based Firms in the 1990s, pp 168-88. Paul Chapman, London. 